\title{
Analysis on the Transformation of Marketing Strategy under the Background of Network Economy
}

\author{
Chong Chen \\ Jianghan University \\ Wuhan 430056 China
}

\begin{abstract}
The interactive update of the Internet and mobile communications has promoted the development of the network economy, and the emergence of the network economy has brought marketing into a new era. In the era of the Internet, traditional marketing in the context of the Internet economy has had a tremendous impact. In this environment, companies that want to not affect or increase product sales must transform traditional sales concepts and reanalyze the specific needs of consumers and make appropriate changes. Therefore, after analyzing the law of network economic operation and network marketing theory, this study briefly expounded the necessity analysis of the change of marketing strategy in the era of network economy and the analysis of consumer consumption trends. Finally, combined with the current market environment, the relevant strategies of marketing in the context of network economy are proposed.
\end{abstract}

Keywords-Network Economy; Marketing Strategy; Strategy Change

\section{INTRODUCTION}

In recent years, the development of computer technology, network technology and communication technology is gradually affecting the mode of enterprise marketing, which has caused profound changes. With the advent of the era of network economy, the traditional marketing model can fully adapt to the changes in modern production methods and consumption patterns [1]. Especially with China's accession to the WTO, various production enterprises are facing greater challenges while facing market expansion and opportunities. As an emerging marketing method, network marketing has a very broad space for development.

In the era of network economy, enterprise development faces various new opportunities and encounters many challenges. Every business needs marketing, and in what way can it survive in such a competitive environment. This requires the use of marketing strategies to motivate companies to use their limited resources to realize more potential and maximize their enthusiasm to create greater value [2]. Therefore, enterprises must strengthen the change and innovation of marketing strategies, use diversified and more advanced technology to shape corporate image, and enable enterprises to embark on the road of sustainable development.

Therefore, after analyzing the law of network economic operation and network marketing theory, this study briefly expounded the necessity analysis of the change of marketing strategy in the era of network economy and the analysis of consumer consumption trends. Finally, combined with the current market environment, the relevant strategies of marketing in the context of network economy are proposed. Hoping that the content of this research could optimize the marketing level of the enterprise in an all-round way and make an important contribution to the development of the enterprise.

\section{NETWORK ECONOMY OPERATION DISCIPLINE AND NETWORK MARKETING THEORY}

Before analyzing the transformation of marketing strategy in the context of network economy, it is necessary to understand the discipline of network economic operation and network marketing theory.

\section{A. The discipline of network economic operation}

The network economy is an economic activity through the Internet, which has become a fashion and trend in the new century. It is mainly represented by a new business model based on the Internet and e-commerce, as well as the development of related information industry and service industry. In the current information age we are in, the economy is more dependent on the development of technology (especially information technology) than ever before [3]. The rapid development of information technology has greatly promoted the development of the network economy. The operating law of the network economy is shown in Fig. 1. 


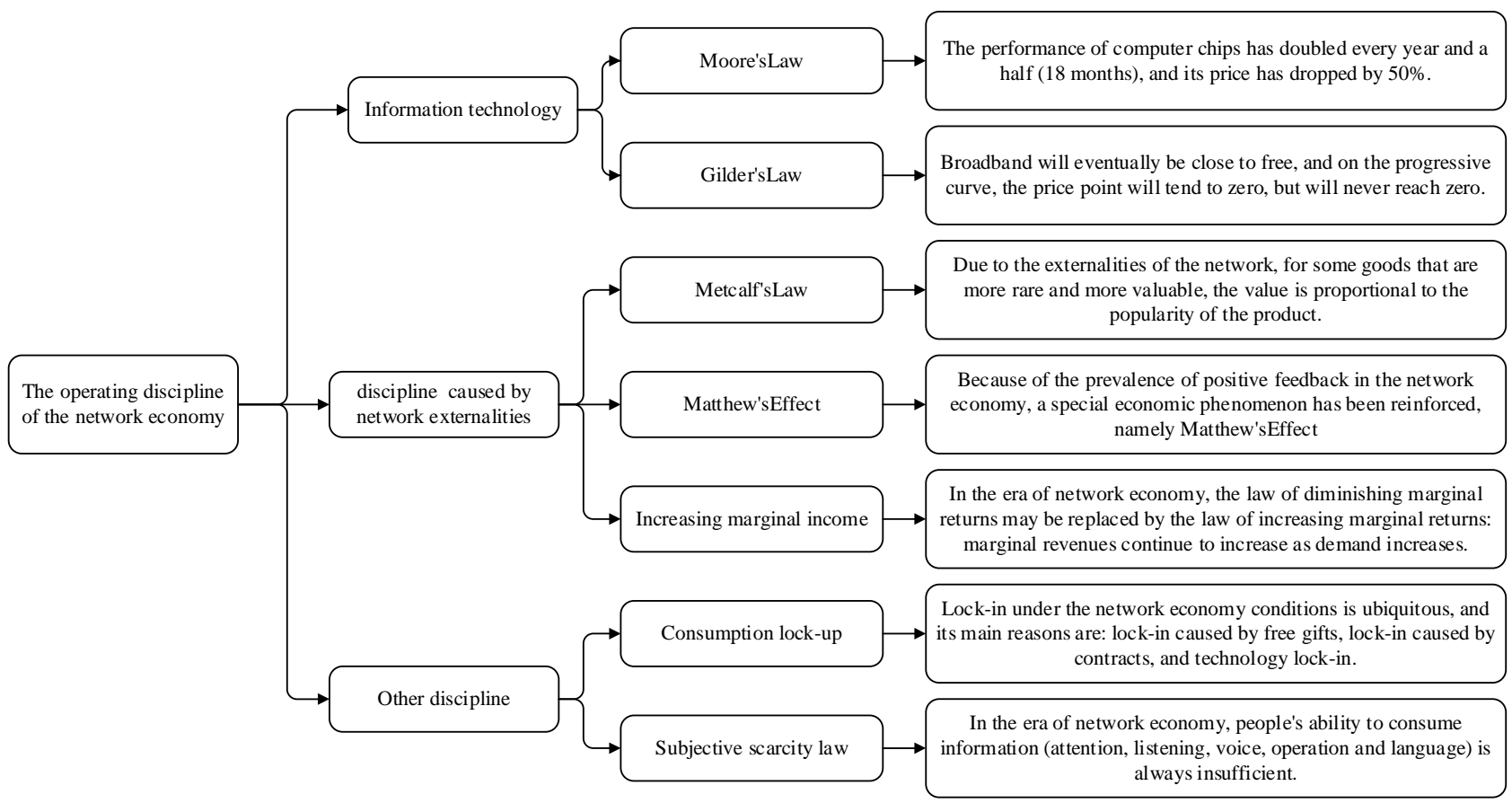

Fig. 1 The operating discipline of the network economy

\section{B. Network marketing theory}

\section{1) Characteristic analysis}

A new marketing model has emerged. Due to the development and the maturity of the mechanism, people have received extensive attention and deep attention. Continuously improve the operation mechanism of the enterprise, and drive the marketing of the enterprise to maximize its potential according to the advantages of the enterprise. Enterprise marketing in the era of network economy refers to the management process of providing products or services to customers through the use of computers, communications and Internet technologies in a massive market environment, while disseminating information on enterprises and products. Marketing in the era of network economy is based on the Internet platform, so it has the characteristics of massive information, strong information acquisition, strong interaction and digitization. The biggest drawback of the network economy era to bring the greatest benefits to corporate marketing is that the amount of information is too large. Enterprises carry out marketing demand information, but excessive information will also increase corporate marketing barriers. The phenomenon of " $\mathrm{a}$ huge amount of information and a lack of knowledge" exists in enterprises [4]. This is an inevitable difficulty for companies to carry out marketing. The vitality of an enterprise lies in the market. The driving force for expanding the market lies in the marketing of the enterprise. The quality of the information used is directly related to the success of the marketing of the enterprise. Therefore, the focus of enterprise marketing in the era of network economy is to make good use of information.

\section{2) Analysis of the information environment of network marketing}

In traditional marketing, getting information about customers and consumers has always been the goal of marketing. Customers influence purchase decisions because they cannot fully grasp product and service information; Company lost many potential business opportunities because it could not get relevant information in time. The information environment faced by corporate marketing in the era of network economy is global, and the Internet allows information to come from any corner of the world. For companies, getting information is no longer a problem; it can be said that the rapid development of computers and information technology has created an unprecedented information environment for marketing and customers. This is mainly reflected in several aspects as shown in Fig. 2.

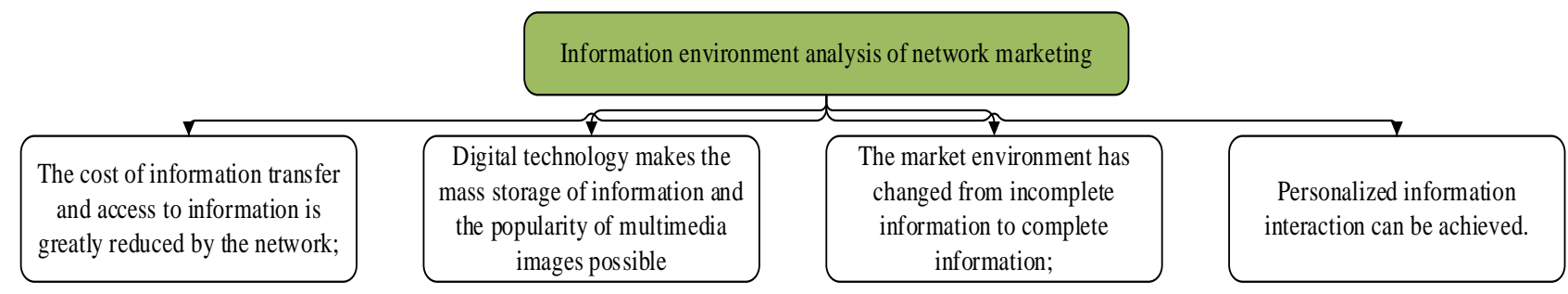

Fig. 2 Information environment analysis of network marketing 
III. ANALYSIS OF THE NECESSITY OF THE TRANSFORMATION OF MARKETING STRATEGY IN THE AGE OF NETWORK ECONOMY AND ANALYSIS OF CONSUMER CONSUMPTION TRENDS

If enterprises want to be based on the market, relying on traditional marketing strategies can no longer meet the diversified needs of consumption. Only by rapidly integrating into the Internet era and catering to the economic market and the masses of consumers can we improve the economic efficiency of the enterprise and achieve long-term development.

\section{A. Analysis of the necessity of the transformation of} marketing strategy in the age of network economy

In the era of network economy, it is necessary for enterprises to analyze the necessity of marketing strategy transformation [5]. The aspects to be considered are shown in Table 1.
TABLE I. ANALYSIS OF THE NECESSITY OF THE TRANSFORMATION OF MARKETING STRATEGY IN THE AGE OF NETWORK ECONOMY

\begin{tabular}{|l|l|}
\hline \multicolumn{1}{|c|}{ Aspects } & \multicolumn{1}{c|}{ Reasons } \\
\hline $\begin{array}{l}\text { Expand } \\
\text { market } \\
\text { space }\end{array}$ & $\begin{array}{l}\text { The Internet is open to the public, and it is extremely open } \\
\text { and inclusive. It can fundamentally break through the limits } \\
\text { of geography and time and space, and achieve round-the- } \\
\text { clock operation. }\end{array}$ \\
\hline $\begin{array}{l}\text { Production } \\
\text { and } \\
\text { consumption } \\
\text { changes }\end{array}$ & $\begin{array}{l}\text { In the Internet age, consumers can view all kinds of product } \\
\text { information online, and they can familiarize themselves with } \\
\text { the products more intuitively and visually, and choose the } \\
\text { right products. }\end{array}$ \\
\hline $\begin{array}{l}\text { Multiple } \\
\text { trading } \\
\text { methods }\end{array}$ & $\begin{array}{l}\text { Online payment is fast, efficient, and simple, and it is more } \\
\text { prominent than cash payment, such as WeChat and Alipay. As } \\
\text { trading methods change, it is important to adjust your } \\
\text { marketing strategy as quickly as possible. }\end{array}$ \\
\hline
\end{tabular}

B. Analysis of consumers' consumption trends in the age of network economy

In the era of network economy, consumers' consumption views show several new trends (Fig. 3):

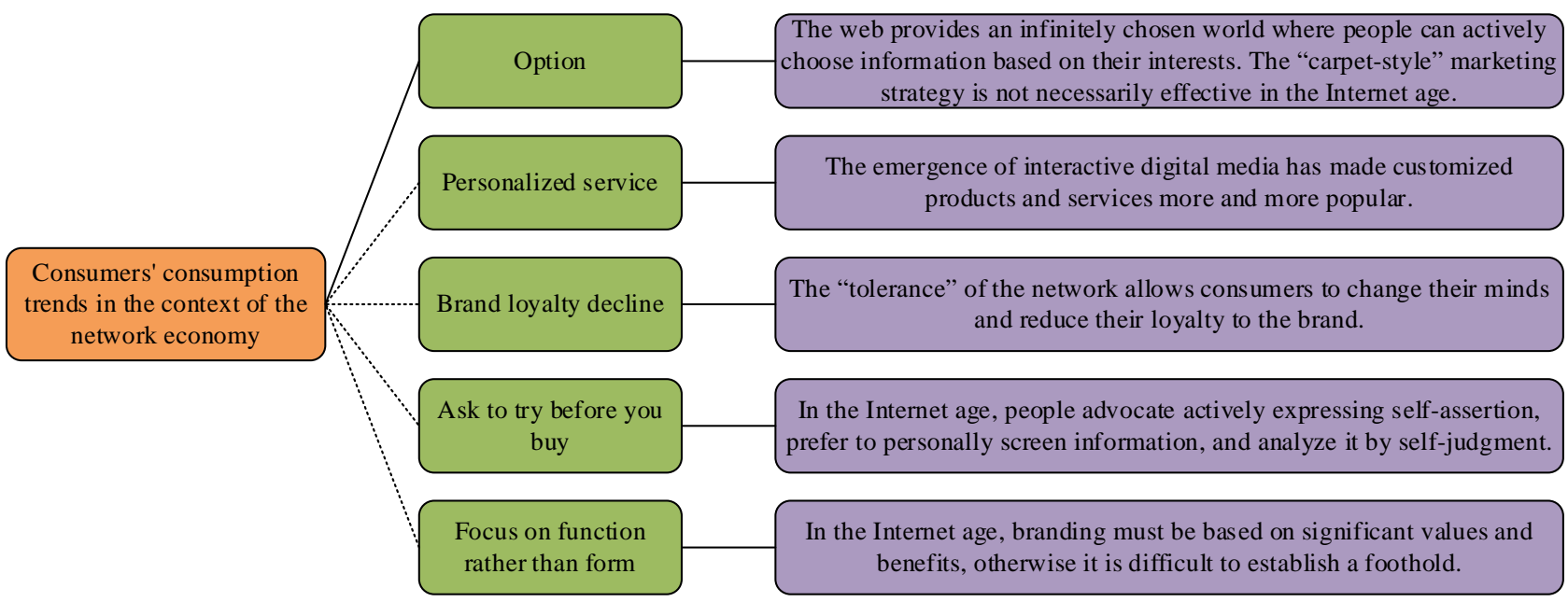

Fig. 3 Consumers' consumption trends in the context of the network economy

These trends pose new challenges for marketing in the Internet age, forcing companies to think about ways and means to meet this challenge.

\section{RESEARCH ON THE TRANSFORMATION PATH OF MARKETING STRATEGY IN THE BACKGROUND OF NETWORK ECONOMY}

The marketing model of products in the era of network economy should start from the demand for consumption. Marketing decision 4P is to maximize the profit of the enterprise under the premise of satisfying 4C, and finally realize the satisfaction of consumer demand and the maximization of corporate profits. Under the new marketing model, the relationship between the company and the customer has become very close and even unbreakable. This forms a "one-on-one" marketing relationship. This marketing framework is called the online marketing model. It always reflects the customer-oriented and continuous interaction between the company and the customer.

\section{A. Strategic shift of enterprise product website}

It is very important for enterprises to conduct online marketing of products and build their own websites. In terms of the planning strategy of the website, enterprises can use their own web pages and use multimedia technology to display the company's growth experience, production process, corporate culture, system construction, technical strength, incentive policies, business concepts and business strategies to customers in all aspects. When you open a web page, the customer is like being in the business. At the same time, real-time updates and maintenance are needed to show every change in the company to the customer. And send a special person to be responsible for the enterprise BBS 24 hours a day, communicate with customers in two-way, listen to customers' opinions and suggestions to the company; In terms of the promotion strategy of the website, enterprises can only guide consumers to enter their own websites by promoting their own websites. This will enable consumers to reach out to the company's products and information, thereby affecting consumers' purchasing decisions [7]. The main platform for website promotion is the network, and the channels or methods used for dissemination are 
relatively common with popular website promotion tools and resources. Including search engines, catalogs, emails, website links, online yellow pages and classified ads, e-books, free software, online advertising media and traditional promotion channels. In terms of website brand planning strategy, online brand name should be created on the network. First, it must be true. The online product information must be accurate, and the product entity should be consistent with the quality of advertising.

\section{B. Product Strategy Innovation}

In the implementation of network marketing, the brand effect can be strengthened. The traditional market environment is mainly reflected in the quality of products and the quality of services, and does not pursue excessive brand effects. Therefore, enterprises should focus on creating a brand effect and increase publicity. At the same time, the company's operating efficiency will inevitably become more ideal, and establish a good brand image for the company. In this way, we can better enhance the intangible assets of the company as the basis for the development of the company. The brand acts as an intangible asset, but it can promote the development of the company and enhance its market competitiveness. Network platform for consumers, information is public. So create a brand and create a personalization. Attract consumers to the corporate network and use the network to get their own brand. Every consumer can understand the product and gain the trust of the public. In addition, big data analysis should be done. Internet marketing can reflect the sales data of commodities and process and analyze them in time [8]. A comprehensive understanding of the sales of goods in the market can reflect the consumer's propensity to consume. In this way, we can more accurately create the products that consumers need and develop marketing strategies that better meet market needs. The relevant steps are shown in Table 2.

TABLE II. PRODUCT STRATEGY INNOVATION STEPS

\begin{tabular}{|c|l|l|}
\hline \multicolumn{2}{|l|}{ Steps } & \multicolumn{1}{c|}{ Measures } \\
\hline Step 1 & $\begin{array}{l}\text { Establish an } \\
\text { automated } \\
\text { service system } \\
\text { on the Internet }\end{array}$ & $\begin{array}{l}\text { Provide quality services through the network } \\
\text { automatically and in a timely manner according } \\
\text { to the needs of customers; Establish a fast and } \\
\text { timely information dissemination system. }\end{array}$ \\
\hline Step 2 & $\begin{array}{l}\text { Establish a } \\
\text { "virtual } \\
\text { exhibition hall" }\end{array}$ & $\begin{array}{l}\text { Use stereoscopic realistic images to showcase } \\
\text { your products with solutions, sounds, etc., so } \\
\text { that consumers can feel the reality of products } \\
\text { if they are immersive. }\end{array}$ \\
\hline Step 3 & $\begin{array}{l}\text { Establish a } \\
\text { virtual assembly } \\
\text { room }\end{array}$ & $\begin{array}{l}\text { Consumers can combine the same product or } \\
\text { different products according to their own needs } \\
\text { to meet the individual needs of consumers. }\end{array}$ \\
\hline
\end{tabular}

\section{Custom Pricing Strategy}

The customized pricing strategy is based on the company's ability to implement customized production, using network technology and auxiliary design software to help consumers choose to conFig. or design their own personalized products that meet their needs. At the same time bear the price costs that you are willing to pay. In the process of setting prices, the products are first tested in the market. On the basis of quality assurance, the price of the product should also be accepted by the public. Therefore, it is necessary to reasonably target the precise positioning of the consumer groups. Understand the purchasing power of consumers and integrate all aspects of information to produce products that meet market needs. Thereby increasing the sales volume of products and obtaining greater economic profits. In the case that the price cannot be discounted, choose to give a small gift, or another way to satisfy the customer's psychological balance. A comprehensive collection of market information and the needs of the public, the target of online marketing is the vast number of consumers [9]. Therefore, we must adapt to the needs of consumers, design and service, and understand the sales market in order to adapt to the development of the market. Therefore, with the help of the network platform, the products are better for consumers. In this way, all-round communication between customers and products can truly meet the needs of consumers and promote the development of the economic market.

\section{Promotion Strategy}

Companies can attract consumers through some special and eye-catching themes to stimulate their desire to buy. In the Internet marketing platform, the information of the goods is completely displayed. When consumers consume online, they can shop around without leaving the house. In the case of the same comprehensive information, consumers will definitely choose products with preferential prices. Therefore, in the promotion, we must promote the performance, design and other aspects of the product, expand the scope of publicity, and the means of propaganda also directly affect the selection criteria of consumers. It is best to promote it on some platforms that are very recognized by consumers. Among these more influential platforms, some stars and fans can greatly enhance the sales of products and publicity. Therefore, as long as the marketing strategy continues to innovate, it can make good use of the Internet platform to promote the development of the enterprise. This transformation of marketing means can better adapt to the market [10]. Meet the needs of consumers and ensure the sustainable development of the company. The marketing strategy of the company has always been dominated by consumers, so innovation is also carried out around consumer demand.

\section{E. Service Strategy}

In marketing activities, providing good service to customers is the key to retaining customers and developing customers in passenger car manufacturers. The service includes pre-sale, sale and after-sales service. In online marketing, pre-sales services mainly introduce customers to common sense, product knowledge, and customer questions through the network; The in-sale service is mainly to provide a good trading platform, convenient settlement method and fast logistics distribution in online transactions; After-sales service is mainly to use the company's website to accept customer complaints, provide various consulting and transmission technical materials. Therefore, it is necessary not only to communicate with the outside world, but also to analyze and formulate a sound marketing strategy from the actual needs of consumers, and to actively innovate. 


\section{F. Community Network Marketing Strategy}

The network virtual community is composed of people with common interests and needs, and a network community with the same interest and online aggregation. Website promoters can participate in discussions, answer questions, and provide help. Take the opportunity to promote the corporate website in the virtual community, as well as conduct online market surveys or customer satisfaction surveys. This method requires no additional investment other than labor costs, and the cost is low. Use community marketing to accurately spread the dispersed audiences, create a real and interactive platform for consumers, and use new network means to expand word-ofmouth communication. And in the continuous dissemination of positive information, consumers gradually recognize the brand value of the passenger car, and take the initiative to maintain it.

\section{CONCLUSION}

The Internet economy is a higher-level economic form that has evolved from the integration of information and communication technologies based on the traditional economy. In the network economy environment, the marketing model should change from satisfying demand to creating demand, and establishing a consumer-centric marketing concept. By paying attention to value growth, we will promote the long-term development of enterprises and at the same time track consumer consumption activities and deepen the understanding of consumers. And we must pay attention to guiding consumers' consumption activities, meeting market demand, broadening the marketing channels of enterprises, and establishing an Internet platform for marketing. And continuously improve the technical level of the company, optimize the marketing level of the enterprise in an all-round way, and make important contributions to the development of the enterprise.

\section{ACKNOWLEDGEMENT}

In this paper, the research was sponsored by the Nature Science Foundation of Henan Province (Project No. 201112400450401) and Youth Fund Project of Luoyang Institute of Science and Technology (Project No. 2010QZ16).

\section{REFERENCES}

[1] Gangeshwer D K. E-commerce or Internet Marketing: A Business Review from Indian Context [J]. International Journal of u-and e-Service, Science and Technology, 2013, 6(6): 187-194.

[2] Mathews S, Bianchi C, Perks K J, et al. Internet marketing capabilities and international market growth[J]. International Business Review, 2016, 25(4): 820-830.

[3] Bianchi C, Mathews S. Internet marketing and export market growth in Chile [J]. Journal of Business Research, 2016, 69(2): 426-434.

[4] Leeflang P S H, Verhoef P C, Dahlström P, et al. Challenges and solutions for marketing in a digital era [J]. European management journal, 2014, 32(1): 1-12

[5] Seo Y. Electronic sports: A new marketing landscape of the experience economy [J]. Journal of Marketing Management, 2013, 29(13-14): 15421560 .

[6] Key T M. Domains of digital marketing channels in the sharing economy [J]. Journal of Marketing Channels, 2017, 24(1-2): 27-38.

[7] Ashley C, Tuten T. Creative strategies in social media marketing: An exploratory study of branded social content and consumer engagement [J]. Psychology \& Marketing, 2015, 32(1): 15-27.

[8] Shaltoni A M. From websites to social media: exploring the adoption of internet marketing in emerging industrial markets [J]. Journal of Business \& Industrial Marketing, 2017, 32(7): 1009-1019.

[9] Golyash I, Panasiuk V, Sachenko S. The performance audit of a corporate website as a tool for its internet marketing strategy [J]. EUREKA: Social and Humanities, 2017 (5): 57-66.

[10] Glavas C, Mathews S. How international entrepreneurship characteristics influence Internet capabilities for the international business processes of the firm [J]. International Business Review, 2014, 23(1): 228-245. 